haemangiomata and other vascular abnormalities leads to a bleeding tendency (Klippel-Trenaunay and Kasabach-Merritt syndromes). ${ }^{3-5}$

Histologically haemangiomata may be capillary, cavernous, mixed capillary and cavernous, or venous. Localised intra-articular haemangiomata may be sessile or pedunculated. The appearance of the synovium, both clinically and histologically, may resemble that of pigmented villonodular synovitis. Although the evidence from animal studies as well as the human models of haemophilia and synovial haemangiomata does not generally bear out the hypothesis that pigmented villonodular synovitis is due to recurrent intra-articular haemorrhage, ${ }^{6} 3$ cases of synovial haemangioma in childhood have been reported in which the synovium was histologically indistinguishable from pigmented villonodular synovitis. ${ }^{7}$ It is important that a search for haemangioma be made whenever a histological report of pigmented villonodular synovitis is obtained on a synovial biopsy in a child.

Synovial haemangiomata may be readily treated by surgical excision and this condition must be considered in the differential diagnosis of monarticular arthritis in childhood.

\section{References}

1 Swann M. Monoarthritis. In: Clinics in rheumatic diseases. Vol. 2. Philadelphia: Saunders, 1976: 369-86.

2 Moon N F. Synovial hemangioma of the knee joint. Clin Orthop 1973; 90: 183-90.

${ }^{3}$ Klippel M, Trenaunay P. Du noevus variqueaux osteohypertrophique. Arch Gen Med (Paris) 1900; 1 : 641-72.

4 Kasabach H H, Merritt K K. Capillary haemangioma with extensive purpura. Report of a case. Am J Dis Child 1940; 59: 1063-70.

5 Resnick D, Oliphant M. Hemophilia-like arthropathy of the knee associated with cutaneous and synovial hemangiomas. Radiology 1975 ; 114 : 323-6.

- Docken W P. Pigmented villonodular synovitis. A review with illustrative case reports. Semin Arthritis Rheum 1979; 9: 1-22.

7 Bobechko W P, Kostuik J P. Childhood villonodular synovitis. Can J Surg 1968; 11 : 480-6.

Correspondence to Dr B M Ansell, Juvenile Rheumatism Unit, Canadian Red Cross Memorial Hospital, Taplow, Maidenhead, Berks SL6 0HN.

Received 28 October 1980

\title{
Infantile flexural seborrhoeic dermatitis. Neither biotin nor essential fatty acid deficiency
}

\section{ERLICHMAN, R GOLDSTEIN, E LEVI, A GREENBERG, AND S FREIER}

\section{Department of Paediatrics, and Laboratories of the Institute of Gastroenterology, Shaare Zedek Medical Centre, Jerusalem}

SUMMARY The allegedly beneficial effect of biotin in the treatment of infantile 'flexural' seborrhoeic dermatitis was evaluated in a double-blind controlled study. No beneficial effect could be confirmed, and it is therefore unlikely that this disease is caused by biotin deficiency. Nor could this scaly dermatitis be ascribed to an essential fatty acid deficiency. Serum and adipose tissue fatty acids resembled each other and reflected the fatty acid composition of the diet.

Infantile seborrhoeic dermatitis is a self-limiting disease which affects the flexures and creases of the skin without any systemic manifestation. Its aetiology is unknown and the adjective 'seborrhoeic' is inappropriate as the sebaceous glands are not affected in the disease process. A paper in this journal ${ }^{1}$ claimed that biotin was effective in its treatment.
The purpose of this investigation was (1) to perform a double-blind controlled trial with biotin, and (2) to evaluate the possibility that a deficiency of essential fatty acids is the cause of the scaly dermatitis. $^{2}$

\section{Patients and methods}

Infants were diagnosed as suffering from seborrhoeic dermatitis if they showed the following features: (1) Onset before age 3 months. (2) Involvement of the flexures, skin creases, including the postauricular region, but not the cheeks. (3) Spontaneous disappearance by 8 months. (4) No pruritus.

The purpose of the double-blind trial was explained to the mothers. Twenty infants received one 5-mg dose orally of biotin or a placebo (glucose) daily for 2 weeks. The parents were asked to stop all topical treatment during the trial. The infants were 
reassessed 2 weeks after onset of the treatment, and fortnightly thereafter until the rash had disappeared.

These 20 patients were part of a group of 44 infants with seborrhoeic dermatitis in whom a fatty acid analysis was made in serum and adipose tissue. Venous blood was obtained after a 12-hour fast and adipose tissue was removed from the buttock by inserting a No 19 needle attached to a syringe and exerting suction. The tissue was placed in a solution of methanol-chloroform $2: 1$, and stored at $-20^{\circ} \mathrm{C}$ until analysis. The fatty acids were analysed by gas-liquid chromatography using standard techniques. ${ }^{3}$

\section{Results}

Controlled trial with biotin. The rash did not clear by 8 months in 2 patients in the biotin group and in 1 patient in the placebo group. Their original diagnosis was therefore revised to infantile eczema. One patient in the biotin-treated group was lost to follow-up.

The results are summarised in Table 1. The two groups were similar in age at onset of rash, age of entry into trial, age of disappearance of the rash, total duration of the illness, and the duration of illness after entry into the clinical trial. There is no evidence that biotin affected the natural course of the disease.

Fatty acid pattern. No essential fatty acid deficiency was found in seborrhoeic dermatitis nor was there a specific fatty acid pattern typical of the condition. However the fatty acid composition of serum and tissue triglycerides did correlate with the infant's diet (Table 2). There were 6 patients receiving breast milk only; these had relatively high concentrations of linoleic acid with quite a small standard deviation $(24.9 \pm 3 \cdot 9)$. Only the group receiving Nutramigen (Mead Johnson and Co.) had higher concentrations of this acid $(36 \cdot 2 \pm 8 \cdot 6)$. When both these groups were compared with the group receiving cows' milk, there was a reciprocal relationship between the linoleic acid concentrations and the others. The C18:1 fraction comprised $45 \%$ of the fatty acids in the cows' milk group and only $32 \%$ in the breast-fed

Table 1 Double-blind study: biotin compared with placebo

\begin{tabular}{|c|c|c|c|c|c|}
\hline \multirow[t]{2}{*}{ Group } & \multicolumn{3}{|c|}{ Age (months) } & \multicolumn{2}{|c|}{$\begin{array}{l}\text { Duration of illness } \\
\text { (months) }\end{array}$} \\
\hline & $\begin{array}{l}\text { At onset } \\
\text { of rash }\end{array}$ & $\begin{array}{l}\text { At entry } \\
\text { to trial }\end{array}$ & $\begin{array}{l}\text { At dis- } \\
\text { appearance } \\
\text { of rash }\end{array}$ & From start & $\begin{array}{l}\text { From start } \\
\text { of biotin or } \\
\text { placebo }\end{array}$ \\
\hline $\begin{array}{l}\text { Biotin } \\
\quad(n=7)\end{array}$ & $0.8 \pm 0.4$ & $2 \cdot 1 \pm 1 \cdot 3$ & $3 \cdot 6 \pm 1 \cdot 6$ & $2 \cdot 8 \pm 2$ & $1 \cdot 3 \pm 0 \cdot 9$ \\
\hline $\begin{array}{l}\text { Placebo } \\
\quad(n=9)\end{array}$ & $1 \cdot 0 \pm 0 \cdot 9$ & $2 \cdot 6 \pm 1 \cdot 1$ & $3.9 \pm 0.9$ & $2 \cdot 9 \pm 1 \cdot 1$ & $1 \cdot 4 \pm 0 \cdot 8$ \\
\hline
\end{tabular}

Table 2 Fatty acid composition of patients' serum triglycerides in various diets (percentage of total fatty acids mean $\pm S D$ )

\begin{tabular}{|c|c|c|c|c|c|}
\hline \multirow{2}{*}{$\begin{array}{l}\text { Fatty } \\
\text { acids }\end{array}$} & \multirow{2}{*}{$\begin{array}{l}\text { Breast } \\
\text { fed } \\
(n=6)\end{array}$} & \multirow{2}{*}{$\begin{array}{l}\text { Cows' } \\
\text { milk } \\
(n=5)\end{array}$} & \multirow{2}{*}{$\begin{array}{l}\text { Nutramigen } \\
(n=6)\end{array}$} & \multicolumn{2}{|c|}{ Initially breast fed } \\
\hline & & & & $\begin{array}{l}\text { Later } \\
\text { cows' } \\
\text { milk } \\
(n=11)\end{array}$ & $\begin{array}{l}\text { Later } \\
\text { comple- } \\
\text { mentary } \\
\text { cows' milk } \\
(n=6)\end{array}$ \\
\hline $\begin{array}{l}12: 0 \\
14: 0 \\
14: 1 \\
16: 0 \\
16: 1 \\
18: 0 \\
18: 1 \\
18: 2 \\
18: 3 \\
20: 4 \\
\text { Others }\end{array}$ & $\begin{array}{r}0.4 \pm 0.3 \\
2 \cdot 1 \pm 0.6 \\
0.3 \pm 0.2 \\
26.9 \pm 2 \cdot 1 \\
4 \cdot 1 \pm 0.9 \\
4.4 \pm 0.8 \\
32.6 \pm 4 \cdot 5 \\
24.9 \pm 3 \cdot 9 \\
0.5 \pm 0.7 \\
2.0 \pm 1 \cdot 2 \\
1.7 \pm 2 \cdot 1\end{array}$ & $\begin{array}{r}0.4 \pm 0.2 \\
3 \cdot 1 \pm 0.7 \\
0.6 \pm 0.2 \\
33.5 \pm 1.7 \\
8.6 \pm 1.6 \\
4.9 \pm 1.6 \\
45.0 \pm 3 \cdot 1 \\
3.3 \pm 1 \cdot 4 \\
0.0 \\
\overline{0.4} \\
\end{array}$ & $\begin{array}{r}0.3 \pm 0.6 \\
1.7 \pm 1.0 \\
0.3 \pm 0.2 \\
23 \cdot 5 \pm 4 \cdot 8 \\
4 \cdot 2 \pm 0.7 \\
3 \cdot 3 \pm 0.9 \\
29.0 \pm 4 \cdot 0 \\
36 \cdot 2 \pm 8 \cdot 6 \\
0.4 \pm 0.5 \\
1 \cdot 7 \pm 1.0 \\
0.2 \pm 0.4\end{array}$ & $\begin{array}{r}0.5 \pm 0 \cdot 3 \\
4 \cdot 4 \pm 1 \cdot 4 \\
0 \cdot 7 \pm 0 \cdot 3 \\
33 \cdot 5 \pm 2 \cdot 1 \\
7 \cdot 9 \pm 2 \cdot 0 \\
5 \cdot 0 \pm 1 \cdot 1 \\
42 \cdot 0 \pm 3 \cdot 5 \\
5 \cdot 4 \pm 2 \cdot 2 \\
0 \cdot 1 \pm 0 \cdot 2 \\
0 \cdot 4 \pm 0 \cdot 5 \\
0 \cdot 5 \pm 0.4\end{array}$ & $\begin{array}{r}0.6 \pm 0 \cdot 5 \\
3 \cdot 9 \pm 1 \cdot 2 \\
0 \cdot 6 \pm 0 \cdot 1 \\
30 \cdot 6 \pm 2 \cdot 6 \\
5 \cdot 6 \pm 2 \cdot 0 \\
5 \cdot 0 \pm 1 \cdot 3 \\
36 \cdot 4 \pm 1 \cdot 6 \\
14 \cdot 4 \pm 5 \cdot 7 \\
0 \cdot 2 \pm 0 \cdot 3 \\
2 \cdot 7 \pm 2 \cdot 2 \\
1 \cdot 1 \pm 1 \cdot 5\end{array}$ \\
\hline
\end{tabular}

infants. High concentrations of linoleic acids correlated with linolenic (18:3) acid. Infants who had been initially only breast fed and later received complementary feeds of cows' milk in addition to human milk had linoleic acid concentrations intermediate between the human and cows' milk groups with corresponding adjustments of the short chain fatty acids. Infants who were initially breast fed for variable periods but were on cows' milk alone at the time of investigation did not differ significantly from the cows' milk group.

The cholesterol ester fraction differed from the triglyceride fraction by the greater proportion of longer chain fatty acids linoleic (18:2), linolenic (18:3), and arachidonic (20:4), the others being proportionately reduced. Infants who were wholly or partly breast fed, and those on Nutramigen, had the highest levels of arachidonic (24:0) and linoleic (18:2) acids in the cholesterol ester fraction and those on cows' milk had lower concentrations.

Table 3 gives values of fatty acids in adipose

Table 3 Fatty acid composition of adipose tissue triglycerides in various diets (percentage of total fatty acids, mean $\pm S D$ )

\begin{tabular}{|c|c|c|c|c|c|}
\hline \multirow{2}{*}{$\begin{array}{l}\text { Fatty } \\
\text { acids }\end{array}$} & \multirow{2}{*}{$\begin{array}{l}\text { Breast } \\
\text { fed } \\
(n=6)\end{array}$} & \multirow{2}{*}{$\begin{array}{l}\text { Cows' } \\
\text { milk } \\
(n=6)\end{array}$} & \multirow{2}{*}{$\begin{array}{l}\text { Nutramigen } \\
(n=6)\end{array}$} & \multicolumn{2}{|c|}{ Initially breast fed } \\
\hline & & & & $\begin{array}{l}\text { Later } \\
\text { cows' } \\
\text { milk } \\
(n=11)\end{array}$ & $\begin{array}{l}\text { Later } \\
\text { comple- } \\
\text { mentary } \\
\text { cows' milk } \\
(n=5)\end{array}$ \\
\hline $\begin{array}{l}12: 0 \\
14: 0 \\
14: 1 \\
16: 0 \\
16: 1 \\
18: 0 \\
18: 1 \\
18: 2 \\
18: 3 \\
\text { Others }\end{array}$ & $\begin{array}{r}1 \cdot 9 \pm 0.5 \\
6 \cdot 2 \pm 0.6 \\
0.7 \pm 0.3 \\
28 \cdot 2 \pm 4.4 \\
9.2 \pm 1 \cdot 8 \\
2.8 \pm 0.7 \\
35 \cdot 1 \pm 2 \cdot 5 \\
15.4 \pm 4.4 \\
0.5 \pm 0.7 \\
0.1 \pm 0.1\end{array}$ & $\begin{array}{r}1.1 \pm 0.6 \\
5.8 \pm 0.6 \\
1.2 \pm 0.4 \\
37.0 \pm 2.6 \\
12.7 \pm 1.2 \\
3.6 \pm 0.8 \\
34.9 \pm 1.6 \\
3.1 \pm 0.7 \\
0.0 \\
0.5 \pm 0.3\end{array}$ & $\begin{array}{r}0.4 \pm 0.3 \\
3.2 \pm 1 \cdot 2 \\
0.5 \pm 0.3 \\
27.6 \pm 2.9 \\
8.4 \pm 1 \cdot 2 \\
2.7 \pm 0.8 \\
33 \cdot 1 \pm 3 \cdot 8 \\
23.6 \pm 9.4 \\
0.3 \pm 0.5 \\
0.2 \pm 0.1\end{array}$ & $\begin{array}{r}1 \cdot 5 \pm 0.5 \\
5 \cdot 9 \pm 1 \cdot 4 \\
1 \cdot 0 \pm 0.4 \\
31 \cdot 6 \pm 3 \cdot 8 \\
10.7 \pm 1 \cdot 3 \\
3.4 \pm 0.7 \\
35 \cdot 5 \pm 2 \cdot 3 \\
9.9 \pm 4 \cdot 3 \\
0.3 \pm 0.3 \\
0.2 \pm 0.2\end{array}$ & $\begin{array}{r}1 \cdot 9 \pm 0.3 \\
6.9 \pm 0.4 \\
0.7 \pm 0.2 \\
33 \cdot 0 \pm 4 \cdot 6 \\
10 \cdot 0 \pm 2 \cdot 5 \\
3 \cdot 5 \pm 0.9 \\
33 \cdot 8 \pm 3 \cdot 9 \\
10 \cdot 0 \pm 4 \cdot 8 \\
0.1 \pm 0.0 \\
0.0 \pm 0.1\end{array}$ \\
\hline
\end{tabular}


tissue. If these are compared with the serum triglyceride concentrations (Table 2) the following conclusions can be drawn. In breast-fed and Nutramigen-fed infants concentrations of C18:2 were higher in the serum than in adipose tissue, and the reverse was true for C18:1 and the shorter chain fatty acids. In the cows' milk group amounts of 18:2 were low and comparable in both tissue and serum. Infants initially breast fed, but receiving cows' milk at the time of investigation, had higher levels of 18:2 in adipose tissue than in serum. Mean serum cholesterol levels were $133 \pm 21 \mathrm{mg} / 100 \mathrm{ml}$ (3.44 $\pm 0.54 \mathrm{mmol} / \mathrm{l})$ in the breast-fed infants, $132 \pm 11 \mathrm{mg} / 100 \mathrm{ml}(3.42 \pm 0.28 \mathrm{mmol} / \mathrm{l})$ in the infants fed on cows' milk, and $104 \pm 24 \mathrm{mg} / 100 \mathrm{ml}$ $(2.69 \pm 0.62 \mathrm{mmol} / \mathrm{l})$ in the infants given Nutramigen. The Nutramigen group had significantly lower levels than the other groups $(\mathrm{P}<0.05)$.

\section{Discussion}

Our trial did not show any appreciable effect of biotin on the natural history of seborrhoeic dermatitis. Our series differed from others in that the drug was given by mouth, and the total dose was 14 times larger than in other trials. We feel that a more critical attitude should be adopted in the treatment of infantile seborrhoeic dermatitis with biotin. Barness has suggested that a number of chemical parameters be used to establish the existence of biotin deficiency before it is given. ${ }^{4}$ These include the evaluation in blood and urine of biotin, propionate, and $\beta$-hydroxy-iso-valeric acid.

Our results show that seborrhoeic dermatitis is not related to a deficiency of linoleic acid. The fatty acid composition of serum and adipose tissue reflected the infant's diet. It was found that infants who had been put on Nutramigen before referral to us had attained a similar concentration of $36.2 \%$ linoleic acid after 1 month on this formula. Nutramigen contains vegetable oil which when analysed in our laboratory was found to contain $73 \%$ of linoleic acid. Breast-fed infants attained only $24 \%$ of linoleic acid in serum triglycerides by the time they were examined by us. The linoleic acid content of breast milk can be up to $45 \%$.

At birth the linoleic acid content of serum is about $1-3 \% .^{5}$ Our infants, examined at a mean age of about 3 months, showed that when a high linoleic acid diet was supplied, this acid was readily incorporated in the fatty acid profile of the serum triglycerides at the expense of the shorter chain fatty acids. It has been shown that even by age one month a high linoleic acid diet is reflected in the adipose tissue concentration of infants. ${ }^{6}$
The cholesterol ester fraction of the serum contained much higher proportions of C18:2, C18:3, and $\mathrm{C} 20: 4$ than the triglyceride fraction. Breast-fed infants had more C20:4 in this fraction than the Nutramigen-fed infants compared with C18:2 which was higher in the Nutramigen group. If serum and adipose tissue profiles are compared it will be noticed that there appears to be a gradient from serum to adipose tissue in the high linoleic acid groups (human milk and Nutramigen), while the non-essential fatty acids are still higher in the adipose tissue. This suggests that complete equilibration had not yet taken place though the rapidity with which adipose tissue incorporates linoleic acid is faster than described for adults.

The levels of cholesterol were similar in the cows' milk and the breast-fed groups. It has been stated that here is an inverse relationship between linoleic acid and cholesterol in the blood. ${ }^{7}$ While this appears to be true for Nutramigen it did not apply to breast milk in our study.

There is no evidence that seborrhoeic dermatitis is caused by a deficiency of essential fatty acids, or a deficiency of biotin.

We thank TARO Pharmaceutical Laboratories for the free supply of biotin, and the Michael and Adelaide Kennedy-Leigh Foundation for supporting this investigation.

\section{References}

1 Messaritakis J, Kattamis C, Karabula C, Matsaniotis M. Generalised seborrhoeic dermatitis. Arch Dis Child 1975; 50: $871-4$.

2 Hansen A E. Essential fatty acids and infant nutrition. Pediatrics 1958; 21 : 494-501.

3 Fosbrooke A, Tamir I. A modified method for the preparation of methyl-esters of a mixture of medium chain and long chain fatty acids. Clin Chim Acta 1968; 20: 517-22.

4 Barness L A. Letter: Treatment of seborrheic dermatitis with biotin and vitamin B complex. J Pediatr 1972; 81 : 631.

5 Widdowson $E \mathbf{M}$, Dauncey $M$ J, Gairdner D $M T$, Jonxis J H P, Pelikan-Filipkova M. Body fat of British and Dutch infants. Br Med J 1975; i: 653-5.

- Zuleger H, Oette K, Schmidt E. Das Fettsauremuster des Subcutànen Fettgewebes bei Neugeborenen und Sauglingen unter Verschiedenen Ernährungsbedingungen. Monatsschr Kinderheilkd 1973; 121 : 374-6.

? Sweeney M J, Etteldorf J N, Dobbins W T, Somervill B, Fischer R, Ferrell C. Dietary fat and concentrations of lipid in the serum during the first six to eight weeks of life. Pediatrics 1961; 27 : 765-71.

Correspondence to Dr S Freier, Department of Paediatrics, Shaare Zedek Medical Centre, PO Box 293, Jerusalem 91-000, Israel.

Received 15 August 1980 